Edmund Tasak

Aneta Ziewiec

Sebastian Lech

Maciej Malik

Jarosław Kubic

\title{
Zgrzewanie materiałów niejednorodnych w rozjazdach kolejowych
}

\section{Welding of dissimilar metals in the rail crossovers}

\section{Streszczenie}

W pracy przedstawiono wyniki badań wpływu parametrów zgrzewania na właściwości i strukturę złączy zgrzewanych stali szynowej z rozjazdem kolejowym ze staliwa wysokomanganowego (Hadfielda). Jako przekładki zastosowano staliwa austenityczne Cr-Ni o różnej stabilności austenitu. Wyniki badań wykazały, że zastosowanie staliwa austenitycznego o metastabilnej strukturze zapewnia lepsze umocnienie przekładki podczas eksploatacji. Duży wzrost twardości jest wynikiem umocnienia dyslokacyjnego oraz przemiany austenitu w martenzyt. Ponadto wykazano, że zbyt wysoka temperatura w obszarze zgrzewania i nieusunięcie nadtopionych powierzchni łączonych elementów prowadzi do powstania struktury martenzytycznej i tym samym obniżenia właściwości plastycznych złączy zgrzewanych.
Abstract

The paper presents the results of the welding parameters influence on the properties and structure of the rail steel and high-manganese (Hadfield) cast steel railway crossover welded joints). As the spacers used steel $\mathrm{Cr}-\mathrm{Ni}$ austenitic steels with different austenite stability. The results showed that the use of metastable austenitic steel structure provides a better appreciation of slip during use. Large hardness increase is due to dislocation strengthening and transformation of austenite to martensite. Also shown that too high temperature in the welding area and melted surface remedy of joined elements leads to a martensitic structure and thus reduce the plastic properties of welded joints.

\section{Wstęp}

Łączenie materiałów różnorodnych takich, jak staliwo wysokomanganowe i stal węglowa, nastręcza $z$ reguły wiele problemów $z$ uwagi na różne właściwości mechaniczne, elektryczne i przewodność cieplną. Ponadto w procesie łączenia mogą tworzyć się niekorzystne struktury znacznie obniżające właściwości plastyczne złącza. Stąd też właściwą technologię

Prof. dr hab. inż. Edmund Tasak, dr inż. Aneta Ziewiec, inż. Sebastian Lech - AGH Akademia Górniczo-Hutnicza w Krakowie; mgr inż. Maciej Malik, mgr inż. Jarosław Kubic - Kolejowe Zakłady Nawierzchniowe Bieżanów, Kraków. zgrzewania stali manganowej ze stalą węglową, gwarantującą odpowiednie właściwości wytrzymałościowe i plastyczne, opanowało niewiele firm.

Krzyżownice i rozjazdy kolejowe wykonuje się obecnie ze staliwa wysokomanganowego (staliwa Hadfielda GX120Mn13) lub jako elementy kute ulepszane cieplnie powierzchniowo o mikrostrukturze perlitycznej. W ostatnich latach prowadzone są prace nad wprowadzeniem technologii produkcji rozjazdów ze staliwa bainitycznego $[1 \div 8]$. Zgrzewanie materiałów jednorodnych, tzn. kutej krzyżownicy z szyną ze stali perlitycznej, nie nastręcza większych problemów i jest technologicznie opanowane. Krzyżownica ze staliwa austenitycznego wysokomanganowego nie może być bezpośrednio zgrzewana z szyną ze stali węglowej lub węglowo-manganowej ze względu na nieodpowiednią 
jakość połączenia. Dlatego łączenie staliwa wysokomanganowego z szynami wykonuje się metodą zgrzewania przez przekładkę ze staliwa lub stali austenitycznej chromowo-niklowej [9]. Proces łączenia został zastrzeżony patentami $[10 \div 13]$. Oprócz technologii w patencie [10] zastrzeżono również materiał przekładki ze stali austenitycznych X10CrNiTi18-9, X10CrNiNb18-10, X5CrNiNb18-10. W krajowym patencie [11] zamiast procesu zgrzewania przekładki austenitycznej do stali węglowej zastosowano proces napawania stali austenitycznej Cr-Ni na stal węglową i tak napawaną przekładkę zgrzewano następnie ze staliwem wysokomanganowym. Wadą wykonanych połączeń według patentów [10,11] jest przekładka ze stali austenitycznej $\mathrm{Cr}-\mathrm{Ni}$, która jest mniej odporna na ścieranie i już po krótkim okresie eksploatacji na powierzchni tocznej w jej miejscu przekładki może powstać wgłębienie, co powoduje szybkie zużywanie się sąsiadujących obszarów ze staliwa wysokomanganowego i szyny ze stali węglowej.

Zgodnie z opisem patentowym [10] proces łączenia elementów rozjazdów z austenitycznego staliwa manganowego np. krzyżownic czy szyn ze stali manganowej z szyną ze stali węglowej, polega na zastosowaniu wkładki pośredniej z niskowęglowej stali austenitycznej. W pierwszym zabiegu tego procesu zgrzana zostaje wkładka pośrednia z szyną. W drugim zabiegu zgrzewania, po ucięciu wkładki pośredniej na długość poniżej $25 \mathrm{~mm}$, wkładka zostaje zgrzana z elementem ze staliwa manganowego. Po wykonaniu pierwszej zgrzeiny prowadzona jest obróbka cieplna, polegająca na wyżarzaniu w zakresie temperatury $350 \div 1000^{\circ} \mathrm{C}$. Patent [11] zakłada, że obróbka cieplna pierwszej zgrzeiny w wyniku zachodzących procesów dyfuzji doprowadza do wyrównania różnicy koncentracji całkowicie różnych składów chemicznych wkładki pośredniej i stali szynowej, przy czym równocześnie uzyskuje się nie tylko wyrównanie koncentracji w pierwszej zgrzeinie, ale także likwiduje się ewentualnie utworzony martenzyt. Pogląd ten zdaniem autorów niniejszego artykułu jest całkowicie błędny, bowiem jak wykazały badania, obróbka cieplna zgrzeiny stali perlitycznej z austenityczną przekładką ze stali chromowo-niklowej nie likwiduje struktury martenzytycznej w strefie zgrzeiny, ale - przeciwnie - zwiększa ilość i twardość martenzytu [14].

\section{Materiał i metodyka badań}

Materiałem do badań były szyny ze stali R350HT zgrzewane ze staliwem wysokomanganowym GX120Mn13. Jako przekładki zastosowano staliwo austenityczne chromowo-niklowe GX5CrNi19-10 oraz staliwo chromowo-niklowe o obniżonej stabilności austenitu o składzie stali X5CrNi17-7 [12]. W zgłoszonym patencie [12] przekładka ze staliwa austenitycznego chromowo-niklowego ma tak dobrany skład chemiczny, że ma metastabilną strukturę austenityczno-martenzytyczną, a podczas kontaktu koła z główką szyny oprócz umocnienia przez zgniot następuje dalsza przemiana fazowa austenitu w martenzyt i wzrost twardości przekładki. Zjawisko to powinno zapewnić większą trwałość złącza zgrzewanego w porównaniu do dotychczas stosowanych rozwiązań.

Zgrzewanie wykonano na przemysłowej zgrzewarce Schlatter według programu zgrzewania, którego schemat pokazano na rysunku 1. Przykład wykonanego złącza pokazano na rysunku 2, natomiast przekrój wzdłużny na rysunku 3. Badania prowadzono na złączach zgrzewanych o różnej szerokości przekładki austenitycznej oraz wg różnych parametrów.

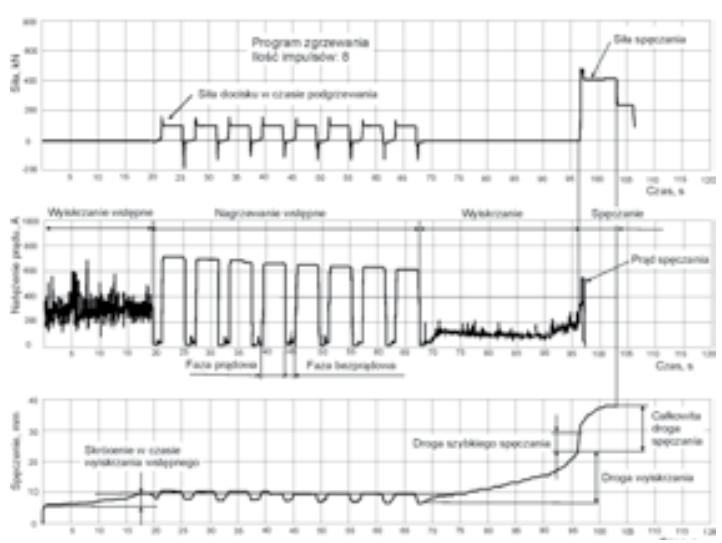

Rys. 1. Schemat zmian parametrów w procesie zgrzewania doczołowego iskrowego

Fig. 1. Butt spark welding process parameters change

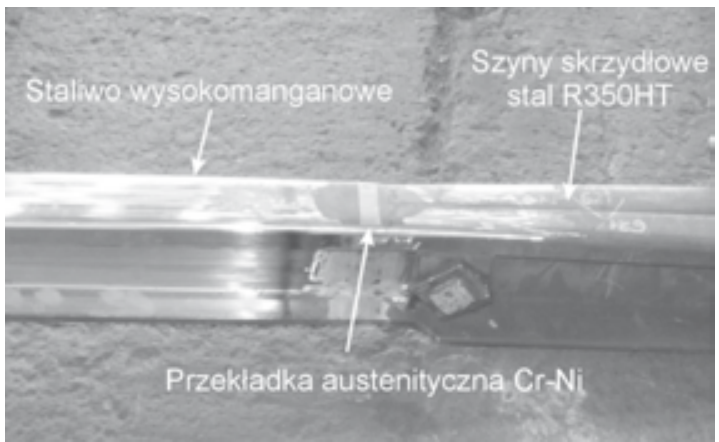

Rys. 2. Złącze staliwa wysokomanganowego z szynami skrzydłowymi przez przekładkę ze stali austenitycznej $\mathrm{Cr}-\mathrm{Ni}$

Fig. 2. Welded joint of high-manganise cast steel with wing rail by spacer of austenitic steel $\mathrm{Cr}-\mathrm{Ni}$

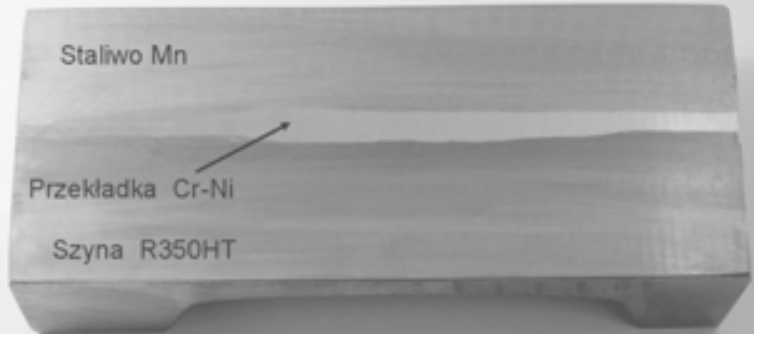

Rys. 3. Przekrój wzdłużny złącza zgrzewanego o średniej szerokości przekładki ok. $5 \mathrm{~mm}$

Fig. 3. Longitudinal section of the welded joints with an average width of about $5 \mathrm{~mm}$ spacers 
Na złączach wykonano:

- technologiczną próbę zginania całego złącza,

- próbę zginania małych próbek wyciętych ze złącza,

- badania nieniszczące i makroskopowe,

- badania mikroskopowe,

- rentgenowską oraz metalograficzną analizę fazową,

- pomiary twardości,

- próby umocnienia i zmian mikrostruktury w czasie odkształcania powierzchni główki szyny.

\section{Wyniki badań}

\section{Próby zginania}

Zgodnie z projektem normy EN 14587-3 (2009) jakość złącza zgrzewanego określa się w próbie zginania statycznego. Odcinek zgrzanych szyn o długości ok. $1150 \mathrm{~mm}$ ustawia się na podporach i zgina na prasie (rys. 4). Trzpień dociskowy powinien znajdować się w miejscu zgrzeiny. Kryterium oceny jest wielkość strzałki ugięcia do pęknięcia oraz siła powodująca pęknięcie. W badanym przypadku pęknięcie złącza wystąpiło przy obciążeniu siłą 1170 kN i strzałce ugięcia 21 $\mathrm{mm}$. Wartości te spełniają wymagania projektu normy EN 14587-3 (2009), w której dla zgrzein szyn R350HT z przekładką austenityczną wymagana minimalna siła niszcząca złącze wynosi 850 kN. Dodatkowo w warunkach technicznych wykonania i odbioru zgrzein w KZN Bieżanów założono minimalną wartość strzałki ugięcia $20 \mathrm{~mm}$.

Aby określić wpływ szerokości przekładki na jakość połączenia zgrzewanego, ze złączy o średniej szerokości przekładki 5 i 0,75 mm wycięto próbki do próby zginania o szerokości $20 \mathrm{~mm}$ i grubości $10 \mathrm{~mm}$. Zginanie prowadzono na trzpieniu $d=3 g$. Próbki zginano na stanowisku pokazanym na rys 5 .

Rysunek 6 ilustruje wygląd próbek po zginaniu. Kryterium jakości złącza był kąt zgięcia do pojawienia się pęknięcia po stronie rozciąganej. Wyniki próby zginania przedstawiono $w$ tablicy I.

Dane w tablicy I wskazują, że przy małej szerokości przekładki kąty zgięcia do wystąpienia pęknięcia są bardzo małe. Cechą charakterystyczną pękania podczas zginania było to, że pęknięcie przebiegało obok linii zgrzania po stronie staliwa manganowego.

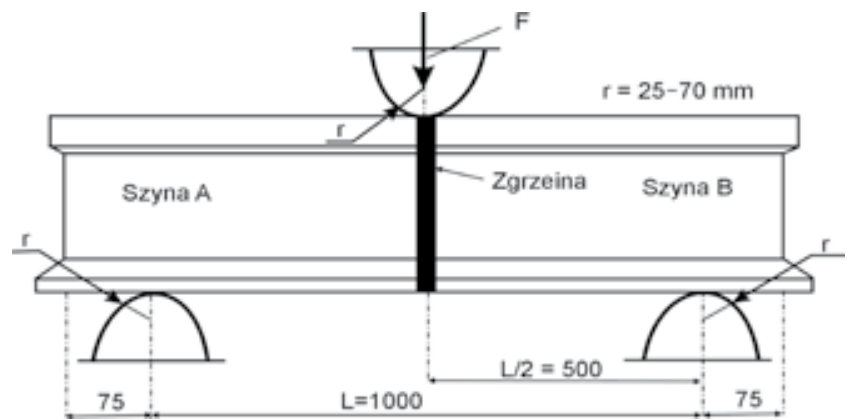

Rys. 4. Schemat stanowiska do zginania złącza zgrzewanego Fig. 4. Spark weld bending test station

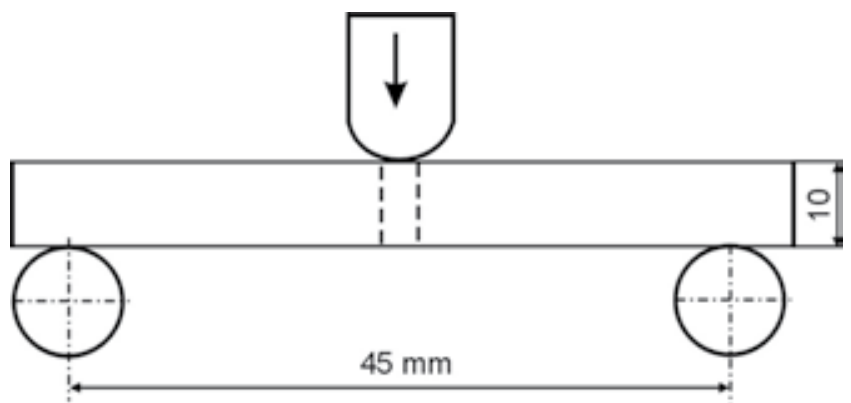

Rys. 5. Schemat stanowiska do zginania próbek złączy zgrzewanych

Fig. 5. Spark weld specimen bending test station

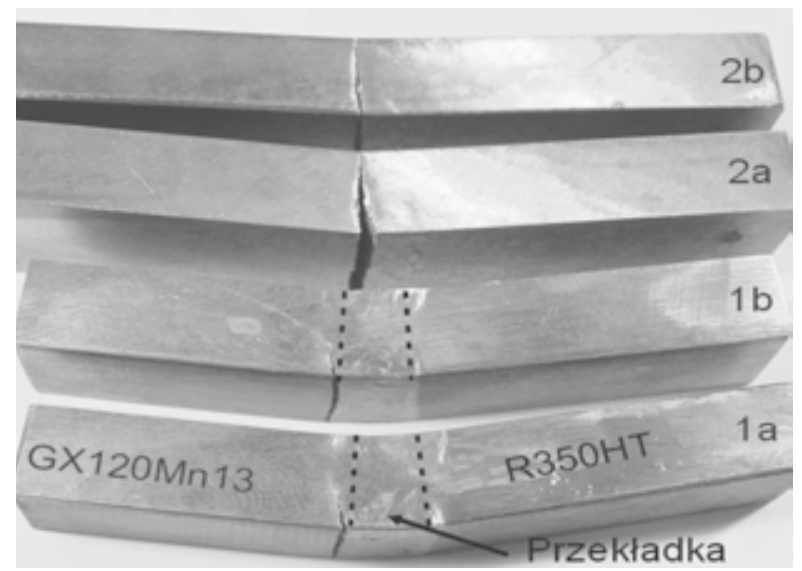

Rys. 6. Próbki po próbie zginania

Fig. 6. Samples after bending test

Tablica I. Kąty zgięcia próbek

Table I. Samples bending angle

\begin{tabular}{|c|c|c|}
\hline Nr próbki & $\begin{array}{c}\text { Szerokość przekładki } \\
\mathrm{mm}\end{array}$ & Kąt zgięcia, $^{\circ}$ \\
\hline $1 \mathrm{a}$ & 5 & 16 \\
\hline $1 \mathrm{~b}$ & 5 & 15 \\
\hline $2 \mathrm{a}$ & 0,75 & 9 \\
\hline $2 \mathrm{~b}$ & 0,75 & 7 \\
\hline
\end{tabular}

\section{Badania nieniszczące i makroskopowe}

Badania penetracyjne wykonanych złączy nie wykazały obecności niezgodności w zgrzeinie. Analiza makroskopowa pierwszych prób zgrzewania wykazała, że szerokość austenitycznej przekładki po zgrzaniu wynosi ok. $15 \mathrm{~mm}$. Była ona jednak zbyt duża, gdyż zgodnie z założeniami powinna wynosić ok. $5 \mathrm{~mm}$. Następne próby zgrzewania wykonane przy skorygowanych parametrach pozwoliły uzyskać właściwą szerokość przekładki w główce szyny ok. $5 \mathrm{~mm}$ (rys. 3). Zwiększenie siły i drogi spęczania spowodowało prawie całkowite usunięcie przekładki.

\section{Badania mikroskopowe}

Badania jakości zgrzein wykonano na próbkach wyciętych z główki szyny szyjki i stopki. Jakość zgrzeiny była taka sama w każdym miejscu, stąd też przedstawione zdjęcia mikrostruktury są reprezentatywne dla całego złącza. Badania przeprowadzono dla 
złączy z przekładką austenityczna ze staliwa GX5CrNi19-10 oraz przekładką austenityczną ze staliwa o składzie stali X5CrNi17-7. Na rysunku 7 przedstawiono mikrostrukturę przekładki staliwa typu 17-7. W strukturze występuje austenit $z$ ferrytem $\delta$ oraz martenzyt $\alpha$ ' powstały podczas chłodzenia po zgrzaniu. Obecność martenzytu wskazuje, że temperatura przemiany martenzytycznej $M_{s}$ jest powyżej temperatury otoczenia. Badania dylatometryczne materiału przekładki [15] wykazały, że temperatura początku przemiany austenitu w martenzyt $\mathrm{M}_{\mathrm{s}}$ wynosi ok. $160^{\circ} \mathrm{C}$. W literaturze jest znanych wiele wzorów, które pozwalają ze składu chemicznego obliczyć temperaturę $M_{\mathrm{s}}$. Obliczone $\mathrm{z}$ tych wzorów temperatury $\mathrm{M}_{\mathrm{s}}$ dla analizowanej przekładki są jednak bardzo rozbieżne od -84 do $+145^{\circ} \mathrm{C}$. Jedynie temperatura $\mathrm{M}_{\mathrm{s}}=145^{\circ} \mathrm{C}$ obliczona z zależności podanej w [16]

$$
\begin{aligned}
M_{s}[K]= & 764,2-302,6(\% \mathrm{C})-30,6(\% \mathrm{Mn})-16,6(\% \mathrm{Ni})+ \\
& -8,9(\% \mathrm{Cr})+2,4(\% \mathrm{Mo})-11,3(\% \mathrm{Cu})+ \\
& +8,58(\% \mathrm{Co})+7,4(\% \mathrm{~W})-14,5(\% \mathrm{Si})
\end{aligned}
$$

jest zgodna $z$ temperaturą $M_{s}$ wyznaczoną dylatometrycznie.

Ilość ferrytu i martenzytu a' określono metodą mikroskopową oraz rentgenowską analizą fazową. Pomiar procentowej zawartości ferrytu $\delta$ metodą mikroskopową polegał na wykonaniu kilkunastu zdjęć mikrostruktury z losowo wybranych obszarów i ich analizie za pomocą programu komputerowego Sigma Scan Pro. Udział objętościowy ferrytu $\delta$ wynosił $8,3 \%$, natomiast martenzytu $\alpha$ ok. $50 \%$. Rentgenowska analiza fazowa pozwalała określić łączny udział ferrytu $\delta$ i martenzytu $\alpha$ '. Średni udział tych faz wynosił ok. $60,3 \%$, co jest w bardzo dobrej zgodności z pomiarami metodą mikroskopowa.

Mikrostruktura przekładki ze staliwa X5CrNi19-10 jest austenityczna z ok. $5 \%$ udziałem ferrytu $\delta$ (rys. 8). Martenzyt $\alpha$ ' w tym staliwie nie występuje.

Obserwacje mikrostruktury zgrzeiny po stronie stali perlitycznej nie wykazały obecności niezgodności typu żużle, wtrącenia, przyklejenia. Można było jedynie stwierdzić wyraźne nadtopienie materiałów w miejscu zgrzania i znaczny stopień wymieszania materiału przekładki ze stalą węglową (rys. 9). Stopiony i wymieszany materiał $w$ miejscu zgrzeiny nie został

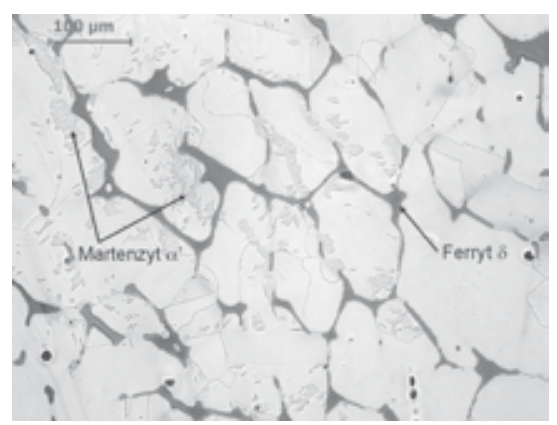

Rys. 7. Mikrostruktura przekładki ze staliwa GX5CrNi19-10. Ferryt $\delta$ (ciemny) i martenzyt $\alpha^{\prime}$ na tle austenitu

Fig. 7. Microstructure of spacer of GX5CrNi19-10 cast steel. Ferrite $\delta$ (dark) and martensite $\alpha$ ' against austenite

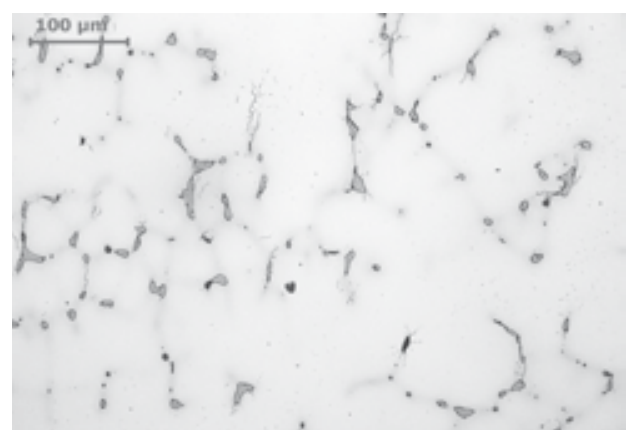

Rys. 8. Mikrostruktura przekładki ze staliwa GX6CrNiNb18-10. Ferryt $\delta$ (ciemny) na tle austenitu

Fig. 9. Microstructure of spacer of GX5CrNi19-10 cast steel. Ferrite $\delta$ (dark) against austenite

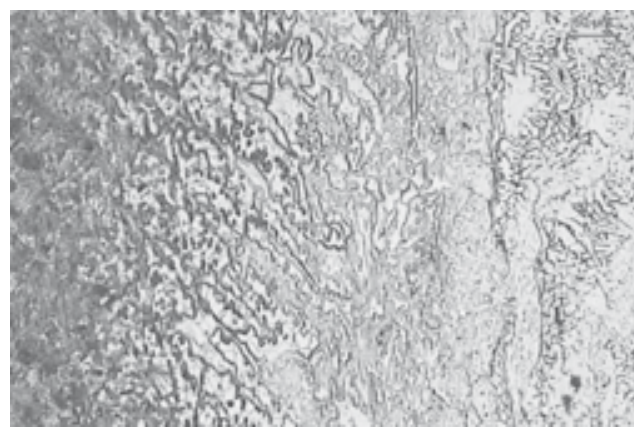

Rys. 9. Mikrostruktura obszaru linii zgrzania przekładki ze stalą szynową. Widoczne znaczne wymieszanie materiałów w miejscu łączenia oraz powstanie niekorzystnej struktury martenzytycznej

Fig. 9. Microstructure of fusion line of spacer and rail steel. Visible good fusion of steels and disadvantageous martensitic microstructure

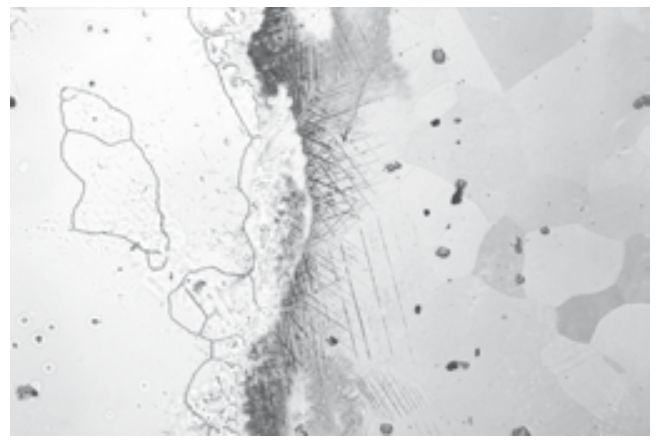

Rys. 10. Mikrostruktura obszaru linii zgrzania przekładki ze staliwem manganowym

Fig. 10. Microstructure of fusion line of spacer and manganese cast steel

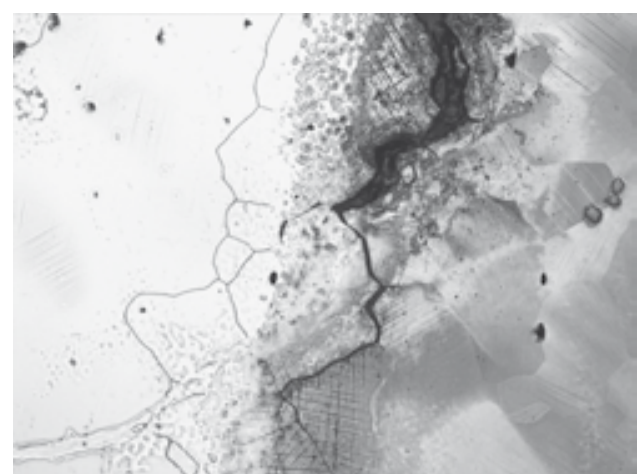

Rys. 11. Przebieg pęknięcia przy linii zgrzania w obszarze występowania pasm fazy $\varepsilon$ i martenzytu $\alpha$

Fig. 11. Crack near to fusion line in the zone of bands of $\varepsilon$ phase and martensite $\alpha$ 


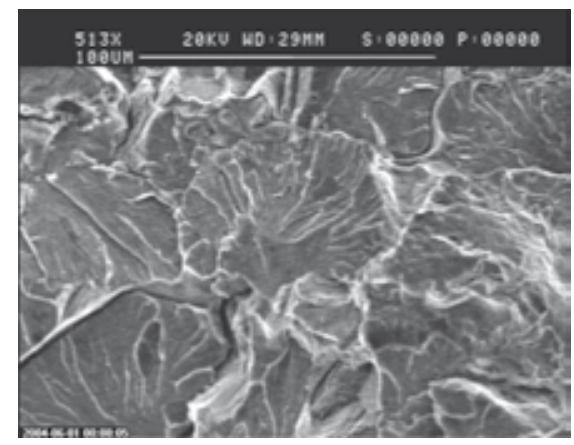

Rys. 12. Kruchy transkrystaliczny i międzykrystaliczny charakter pękania

Fig. 12. Transcrystalline and intercrystalline brittle fracture

usunięty w procesie spęczania. Spowodowało to powstanie struktury martenzytycznej o mikrotwardości mierzonej wgłębnikiem Knoopa 939 HK0,05 (ok. 970 HV) [17]. Wyraźne nadtapianie się granic ziaren w stali perlitycznej świadczy o zbyt wysokiej temperaturze procesu zgrzewania.

Zgrzeina po stronie staliwa wysokomanganowego również nie wykazuje wad. Mikrostrukturę strefy zgrzeiny przedstawiono na rysunku 10 . Staliwo manganowe ma strukturę austenityczną po przesyceniu. Przy linii zgrzania widoczne są wyraźne linie sugerujące, że są to pasma odkształceń. Jednak szczegółowa analiza wykazała, że nie są to pasma odkształceń, lecz pasma fazy $\varepsilon$ (martenzytu $\varepsilon$ ) oraz martenzytu $\alpha$ na przecięciu pasm fazy $\varepsilon$. Fazy te powstają podczas chłodzenia $z$ austenitu manganowego o obniżonej stabilności. Obecność martenzytu potwierdziły badania magnetyczne na stanowisku do mikroskopowej identyfikacji faz magnetycznych [15].

Podstawowym problemem, który należało wyjaśnić podczas badań mikroskopowych, było zjawisko pękania małych próbek podczas zginania po stronie staliwa Hadfielda. Spodziewano się, że najbardziej kruchym obszarem jest obszar linii zgrzania po stronie stali szynowej. W rzeczywistości okazało się, że pękanie przebiega w staliwie Hadfielda w obszarze występowania pasm fazy $\varepsilon$ i martenzytu $\alpha$ ' (rys. 11). Obecność tych faz można wyjaśnić następująco. Nadtopienie materiałów w czasie zgrzewania i nieusunięcie stopionego obszaru w procesie spęczania oraz wolne chłodzenie powoduje dyfuzję węgla i manganu ze staliwa manganowego do austenitycznej przekładki. Austenit manganowy przy zgrzeinie zubożony w węgiel i mangan podczas chłodzenia ulega przemianie $w$ faze $\varepsilon$ i martenzyt $\alpha$ '. Fazy te usytuowane na płaszczyznach typu (111) wywołują pękanie kruche transkrystaliczne (rys. 12).

\section{Badania rozkładu twardości i stopnia umocnienia powierzchni szyny}

Rozkład twardości na przekroju złącza zgrzewanego przedstawiono na rysunku 13. Badania twardości w strefie złącza wykazały, że staliwo austenityczne manganowe ma twardość ok. 230 HV10, przekładka austenityczna ze stali $\mathrm{Cr}$ -
$\mathrm{Ni}$ ok. $210 \mathrm{HV} 10$, natomiast stal szynowa w SWC w pobliżu linii zgrzania ok. 370 HV10. W dalszej odległości ok. $5 \mathrm{~mm}$ od linii zgrzania twardość wynosi ok. 400 HV10.

Aby potwierdzić tezę, że zastosowana przekładka będzie ulegała znacznemu umocnieniu w wyniku odkształcenia powierzchniowego, metoda młotkowania odkształcono przekładkę austenityczną oraz staliwo manganowe w główce szyny. Ubytek wysokości wynosił ok. 0,4 mm przy wysokości próbki $15 \mathrm{~mm}$. Z tak przygotowanej główki szyny wycięto próbki do pomiaru rozkładu twardości pod powierzchnią główki. Wyniki pomiarów przedstawiono na rysunkach $14 \div 16$.

Z wykresów widać, że odkształcanie przekładki austenitycznej $\mathrm{Cr}-\mathrm{Ni} \mathrm{z}$ metastabilnym austenitem spowodowało prawie 2,5-krotny wzrost twardości przy powierzchni do poziomu ok. 510 HV10. Tak duży wzrost twardości jest wynikiem umocnienia dyslokacyjnego i przemiany fazowej austenitu w martenzyt $\alpha$. W staliwie ze stabilnym austenitem (GX5CrNi19-10) twardość wzrasta do poziomu 370 HV10. Niewielki wzrost twardości jest wynikiem tylko umocnienia dyslokacyjnego $\mathrm{W}$ staliwie manganowym

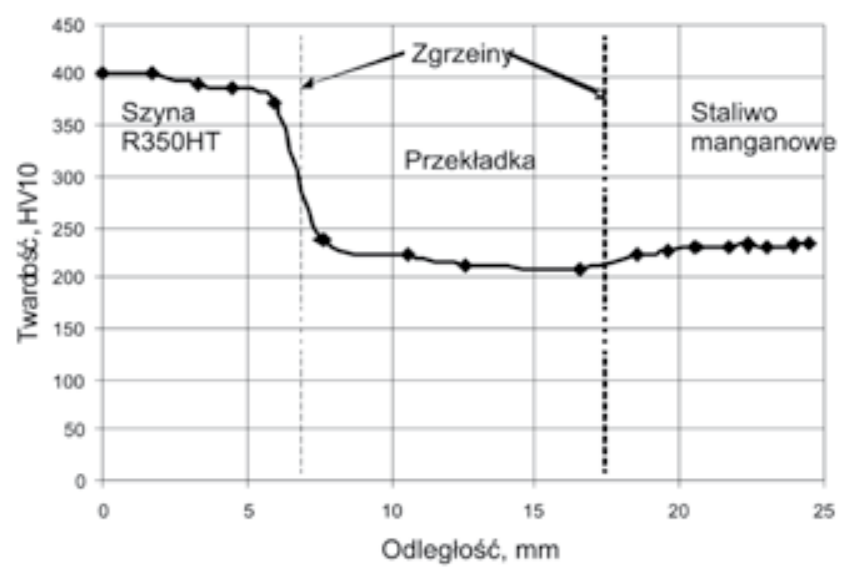

Rys. 13. Rozkład twardości na przekroju złącza zgrzewanego z przekładką ze staliwa GX5CrNi17-7

Fig. 13. Hardness distribution in the cross-section of welded joint with spacer of GX5CrNi17-7 cast steel

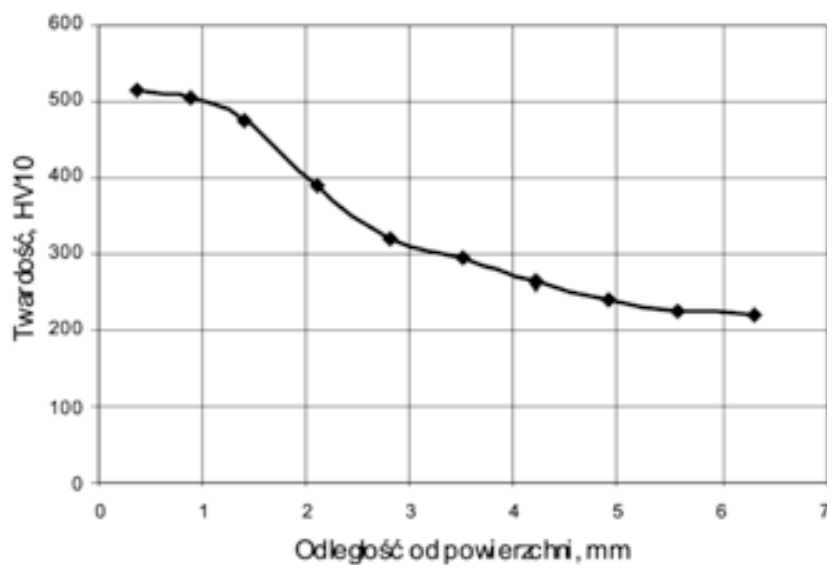

Rys. 14. Rozkład twardości od umacnianej powierzchni w przekładce ze staliwa GX5CrNi17-7

Fig. 14. Hardness distribution in strengthening surface of GX5CrNi17-7 cast steel spacer 


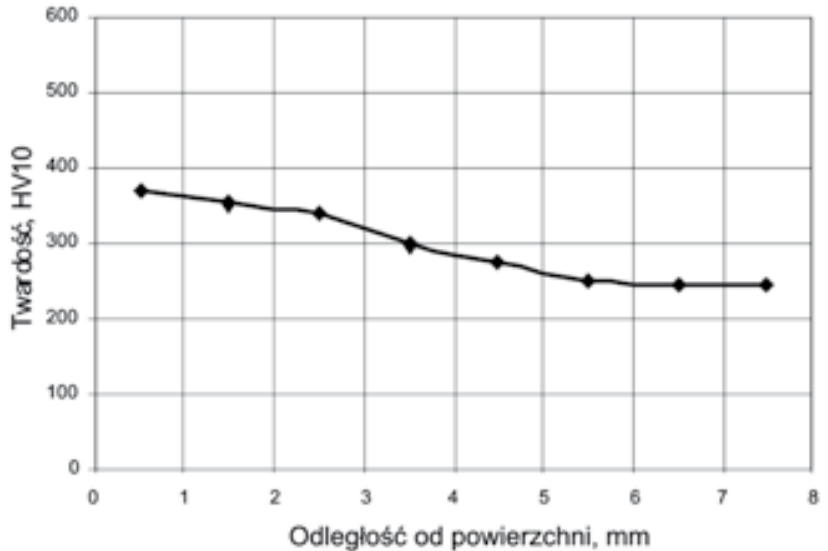

Rys. 15. Rozkład twardości od umacnianej powierzchni w przekładce ze staliwa GX5CrNi19-10

Fig. 15. Hardness distribution in strengthening surface of $\mathrm{GX} 5 \mathrm{Cr}$ Ni19-10 cast steel spacer

odkształcenie spowodowało wzrost twardości 2,6 razy do poziomu ok. 600 HV10. Duży wzrost twardości w staliwie manganowym (Hadfielda) jest wynikiem umocnienia dyslokacyjnego, bliźniakowania oraz przemiany fazowej austenitu w martenzyt $\varepsilon$ i $\alpha$ '. Podobny stopień umocnienia w czasie odkształcania powierzchni główki szyny manganowej i przekładki ze staliwa o składzie stali X5CrNi17-7 z metastabilnym austenitem powinien zapewnić dobrą odporność na zużycie złącza zgrzewanego.

\section{Wnioski}

1. Badania makroskopowe i mikroskopowe połączenia zgrzewanego z przekładką ze staliwa austenitycznego o obniżonej stabilności austenitu wykazały prawidłową geometrię złącza. Linia zgrzania zarówno po stronie staliwa manganowego, jak i stali szynowej nie wykazuje niezgodności spawalniczych. Dowodem tego jest właściwa wartość strzałki ugięcia, wymagany poziom siły niszczenia złącza w czasie próby zginania oraz lokalizacja pęknięcia w materiale stali szynowej R350HT.

2. Struktura przekładki składa się z austenitu, ferrytu $\delta$ oraz martenzytu $\alpha$ '. W czasie współpracy koła z powierzchnią główki będzie zachodziła dalsza przemiana fazowa austenitu w martenzyt $\alpha$, powodująca samoutwardzanie się przekładki, co zapobiegnie tworzeniu się wgłębienia na powierzchni główki szyny w miejscu austenitycznej przekładki.

3. Odkształcenie powierzchni główki szyny w miejscu złącza metodą młotkowania, symulujące umocnienie złącza w czasie eksploatacji, potwierdziło przebieg przemiany fazowej austenit w martenzyt $\alpha$ ' w austenitycznej przekładce ze staliwa X5CrNi17-7 i wzrost twardości do 510 HV10. W przekładce ze staliwa GX5CrNi19-10 ze stabilnym austenitem twardość powierzchni wzrasta do $370 \mathrm{HV} 10$. W odlewie ze staliwa manganowego umocnienie

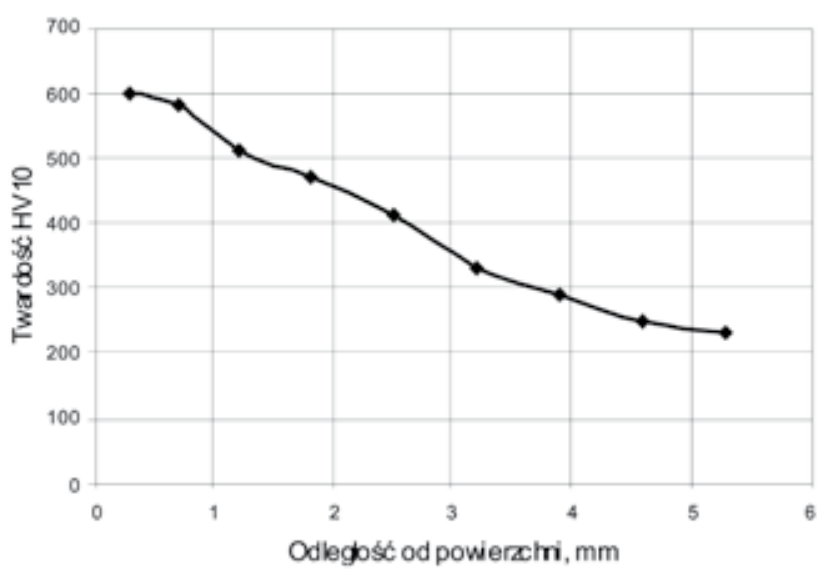

Rys. 16. Rozkład twardości od umacnianej powierzchni staliwa wysokomanganowego GX120Mn13

Fig. 16. Hardness distribution in strengthening surface of $\mathrm{GX} 120 \mathrm{Mn} 13$ high-manganese cast steel spacer

Wykorzystując opracowaną technologię spajania i nowy materiał na przekładki, w KZN Bieżanów wykonano ponad 20 złączy stali szynowej R350HT ze staliwem wysokomanganowym. Złącza te zamontowano w rozjazdach kolejowych na krajowych liniach kolejowych w 2012 r. Okresowe rewizje rozjazdów wskazują na bardzo dobre zachowanie się ich w czasie eksploatacji. powierzchni w wyniku młotkowania powoduje wzrost twardości do 600 HV10. Duży stopień umocnienia przekładki ze staliwa $z$ metastabilnym austenitem zagwarantuje dużą odporność na zużycie złącza zgrzewanego.

4. Zmierzona metalograficznie ilość ferrytu w przekładce ze stali austenitycznej wynosi ok. 8,3\% Udział martenzytu zależy od miejsca pomiaru. W środku szyny udział martenzytu ma wartość ok. $15 \%$, natomiast przy powierzchni nawet $50 \%$. Wyznaczona metodą rentgenowską łączna zawartość ferrytu i martenzytu przy powierzchni wynosi ok. $55 \%$. W strefie umocnionej odkształceniem sumaryczny udział ferrytu $\delta$ i martenzytu to ok. $60 \%$. Wyniki pomiarów ilości ferrytu $\delta$ i martenzytu $\alpha$ wykonane metodą rentgenowskiej analizy fazowej i metalograficznie są więc zbieżne.

5. Stwierdzona niska plastyczność złączy zgrzewanych w pierwszych próbach była wynikiem zbyt wysokiej temperatury $w$ procesie zgrzewania i nieusuwaniem w czasie spęczania nadtopionych obszarów. Skorygowane parametry zgrzewania (ilość impulsów, ustawienie płaszczyzny zgrzewania względem elektrod prądowych, siła docisku) pozwoliły wyeliminować błędy i otrzymać złącza zgrzewane, które spełniają wymagania postawione w odpowiednich przepisach kolejowych. 
6. Przeprowadzone badania złącza zgrzewanego staliwa wysokomanganowego z szyną ze stali węglowej przez przekładkę ze staliwa austenitycznego z metastabilnym austenitem w pełni potwierdziły założenia i oczekiwania stawiane połączeniom zgrzewanym w rozjazdach kolejowych. Zastoso- wanie na przekładkę staliwa austenitycznego o obniżonej trwałości austenitu pozwala uzyskać złącze, w którym w procesie eksploatacji umocnienie staliwa manganowego i przekładki będzie podobne, co wpłynie na wzrost odporności na zużycie.

\title{
Literatura
}

[1] Dobosz S., Pacyna J., Tasak E., Kusiński J.: Nowe tworzywa bainityczne na rozjazdy krzyżownic kolejowych, Projekt rozwojowy nr R0700702 finansowany przez KBN, AGH Kraków 2008-2010.

[2] Gawlik S., Naróg P., Głownia J.: Charakterystyka staliwa bainitycznego na rozjazdy kolejowe, Materiały Konferencji „Staliwo - nowe wyzwania przemysłowe” Kraków 2013.

[3] Parzych S.: Struktura i właściwości połączeń zgrzewanych stali i staliw stosowanych w kolejnictwie, Praca doktorska, AGH Kraków 2012.

[4] Parzych S., Krawczyk J.: The influence of heat treatment on microstructure and tribological properties of resistance butt welds of a cast bainitic steel, Archives of Metallurgy and Materials, vol. 57, issue 1, s. 261-264, 2012.

[5] Parzych S.: Mikrostruktura i właściwości staliwa bainitycznego po różnych wariantach obróbki cieplnej, XXXIX Szkoła Inżynierii Materiałowej, Kraków-Krynica, 27.09-2.10.2011, s. 290-301, 2011.

[6] Parzych S., Tasak E.: Influence of heat treatment on microstructure and properties of bainitic cast steel used for frogs in railway crossovers, Archives of Foundry Engineering, vol. 10, special issue 1, s.113-116, 2010.

[7] Krawczyk J., Parzych S.: Microstructure formation and properties of abrasion resistant cast steel, Archives of Foundry Engineering, vol. 10 special issue 1, s. 295-300, 2010

[8] Parzych S., Tasak E.: Właściwości odlewanych monoblokowych krzyżownic wykonanych ze staliwa bainitycznego, Materiały Konferencji Spawalnictwo dróg szynowych: jakość-niezwodność-bezpieczeństwo, Warszawa-Bochnia, 12-14.05.2010, s.92-97, 2010

[9] Tasak E., Henel G., Żurek Z.: Technologia wytwarzania rozjazdów ze staliwa manganowego spajanego ze stalą węglową, Przegląd Spawalnictwa nr 52007 s. 30-33.
[10] Blaumauer J.: patent EP 0467881 A1 (patent PL 167992): Verfahren zur Verbindung von aus Manganhartstahiguss bestehenden Weichenteilen bzw. Manganstahlschienen mit einer Schiene aus Kohlenstoffstahl, 1991.

[11] Tasak E.: patent P.365917, Sposób łączenia elementów rozjazdowych wykonanych ze staliwa wysokomanganowego i stali szynowej węglowej, 2004.

[12] Tasak E., Ziewiec A., Paś J., Sajon S.: Sposób łączenia elementu $z$ austenitycznego staliwa wysokomanganowego $z$ elementem ze stali węglowo-manganowej lub stali węglowej, zgłoszenie patentowe P.395747 z dnia 25.07.2011.

[13] Tasak E., Ziewiec A., Ziewiec K.: Sposób łączenia elementów rozjazdowych wykonanych $z$ austenitycznego staliwa lub stali wysokomanganowej i szyn ze stali węglowo-manganowej lub węglowej, zgłoszenie patentowe P.400757 z dnia 13.09.2012.

[14] Lech S.: Wpływ grubości przekładki i obróbki cieplnej na właściwości złącza zgrzewanego stali R350HT ze staliwem wysokomanganowym, Referat wygłoszony na 50 . Konferencji Studenckich Kół Naukowych AGH, Kraków 2013.

[15] Formowicz K., Tasak E.: Przemiany fazowe i strukturalne występujące $\mathrm{w}$ procesie zgrzewania staliwa manganowego ze stalą węglową poprzez przekładkę ze stali austenitycznej, Materiały 50. Konferencji Studenckich Kół Naukowych AGH, Publikacje Laureatów, Wyd. Studenckie Towarzystwo Naukowe Kraków 2013.

[16] Capdevila C., Caballero F.G., Garcia de Andres C.: Determination of Ms Temperature in Steels: A Bayesian Neural Network Model, ISIJ International 42 (2002) 894.

[17] Formowicz K.: Właściwości i struktura złączy zgrzewanych staliwa wysokomanganowego z szyną ze stali węglowej, Projekt inżynierski. AGH Kraków 2013.

Badania wykonano $w$ ramach projektu $n r 179178$ umowa $n r$ PBS1/A5/8/2012

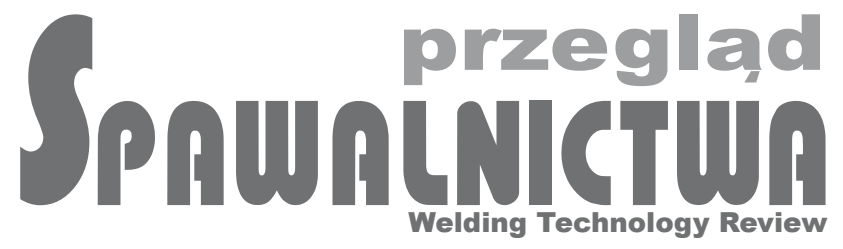

\author{
Redakcja Przegląd Spawalnictwa, ul. Świętokrzyska 14a, 00-050 Warszawa
} tel.: 2282725 42, fax: 2233614 79; e-mail: pspaw@ps.pl, www.pspaw.ps.pl 